Check for updates

Cite this: RSC Adv., 2017, 7, 25378

Received 6th April 2017

Accepted 28th April 2017

DOI: $10.1039 / \mathrm{c} 7 \mathrm{ra03896h}$

rsc.li/rsc-advances

\title{
Benzene-glycol nucleic acid (BGNA)-DNA chimeras: synthesis, binding properties, and ability to elicit human RNase $\mathrm{H}$ activity $\dagger$
}

\author{
Nazuki Niwa, ${ }^{a}$ Saki Shimizu, ${ }^{d}$ Yusuke Maeda, ${ }^{a}$ Hidekazu Hiroak ${ }^{d}$ \\ and Yoshihito Ueno*abc
}

\begin{abstract}
This paper describes the synthesis and properties of benzene-glycol nucleic acid (BGNA)-DNA chimeras containing four nucleoside analogs - thymidine, cytidine, adenosine, and guanosine - with a basebenzene-glycol structure. We found that the BGNA-DNA chimeras are able to form thermally and thermodynamically stable duplexes with complementary RNAs, and have base-discriminating abilities. The BGNA-DNA chimeras were 20 -fold more stable in a buffer containing $30 \%$ bovine serum than unmodified DNA. Furthermore, BGNA-DNA chimera/RNA duplexes were found to be good substrates for human RNase $\mathrm{H}$. Thus, BGNA-DNA chimeras are good candidates for the development of therapeutic antisense molecules.
\end{abstract}

\section{Introduction}

Antisense oligonucleotides (AONs) are single-stranded DNAs consisting of $17-30$ bases that can inhibit translation by binding to complementary target mRNAs. ${ }^{1}$ AONs have recently attracted attention as chemotherapeutic agents, since they can be rationally designed and synthesized given the sequences of disease-causing genes. ${ }^{2}$ Fomivirsen, a drug for cytomegalovirus (CMV) retinitis in patients with acquired immune deficiency syndrome (AIDS), is the first AON drug approved by the U.S. Food and Drug Administration (FDA). ${ }^{3}$ Mipomersen is an AON drug for patients with homozygous familial hypercholesterolemia. Eteplirsen, a drug used to treat patients with Duchenne muscular dystrophy, has also recently been approved by the FDA. ${ }^{4}$

As phosphodiester linkages in DNA are easily hydrolyzed by the nucleases present inside and outside cells, chemical modifications are needed to impart nuclease-resistant properties to DNAs for them to function as antisense drugs. For example, fomivirsen is composed of phosphorothioate linkages instead of natural phosphate linkages. ${ }^{3}$ Mipomersen is partially composed of nucleoside analogs modified with methoxyethyl

${ }^{a}$ Course of Applied Life Science, Faculty of Applied Biological Sciences, Gifu University, Japan. E-mail: uenoy@gifu-u.ac.jp; Fax: +81-58-293-2919; Tel: +81-58-293-2919

${ }^{b}$ United Graduate School of Agricultural Science, Gifu University, Japan

${ }^{\prime}$ Center for Highly Advanced Integration of Nano and Life Sciences (G-CHAIN), Gifu University, 1-1 Yanagido, Gifu 501-1193, Japan

${ }^{d}$ Division of Structural Biology, Graduate School of Pharmaceutical Sciences, Nagoya University, Furo-cho, Chikusa-ku, Nagoya, Aichi 464-8601, Japan

$\dagger$ Electric supplementary information (ESI) available. See DOI: $10.1039 / \mathrm{c} 7 \mathrm{ra03896h}$
(MOE) groups at the $2^{\prime}$-hydroxyl positions. Eteplirsen has a backbone composed of methylenemorpholine rings and phosphorodiamidate linkages.

Recently, we reported the synthesis of two nucleoside analogs, a cytidine analog (1) and an adenosine analog (2), comprising a base-benzene-glycol structure (Fig. 1). ${ }^{5} \mathrm{We}$ found that DNAs partially incorporating the benzene-glycol nucleic acids (BGNAs), termed BGNA-DNA chimeras, form thermally stable duplexes with complementary DNA and RNA, and these duplexes are more resistant to hydrolysis by a snake venom phosphodiesterase (a $3^{\prime}$-exonuclease) than unmodified DNA. As an extension of our study on the synthesis of BGNAs, we report in this paper the synthesis of a thymidine analog (3) and a guanosine analog (4), and properties of BGNA-DNA chimeras containing these four analogs as antisense molecules.

\section{Results and discussion}

\section{Synthesis}

We previously reported the synthesis of the cytidine and adenosine analogs using the Chan-Lam-Evans reaction between an arylboronic acid and nucleobases..$^{5-7}$ Synthesis of the thymidine and guanosine analogs was achieved using the same reaction. To prevent the side reaction between the $N^{3}$ position of thymine and the arylboronic acid, we used an $N^{3}$-protected thymine, $N^{3}$ benzoylthymine, as a substrate for the synthesis of the thymidine analog. To solve the problem of the insolubility of guanine, a protected purine base, 2-bis(tert-butoxycarbonyl)amino-6chloropurine, was used as a substrate for the synthesis of the guanosine analog..$^{5 b}$ The synthetic routes to the thymidine and guanosine analogs, and the corresponding phosphoramidite units (8 and 14, respectively), are shown in Schemes 1 and 2. 
<smiles>Nc1ccn(-c2ccc([C@@H](O)CO)cc2)c(=O)n1</smiles><smiles>Nc1ncnc2c1ncn2-c1ccc([C@@H](O)CO)cc1</smiles>
$1\left(C^{b}\right)$<smiles>Cc1cn(-c2ccc([C@@H](O)CO)cc2)c(=O)[nH]c1=O</smiles><smiles>Nc1nc2c(ncn2-c2ccc([C@@H](O)CO)cc2)c(=O)[nH]1</smiles>

$4\left(G^{b}\right)$
Fig. 1 Structures of the nucleoside analogs.

$N^{3}$-Benzoylthymine was coupled with the arylboronic acid derivative 5 in the presence of $\mathrm{Cu}(\mathrm{OAc})_{2}$ and pyridine as a base in $\mathrm{CH}_{2} \mathrm{Cl}_{2}$ to give an $N^{1}$-aryl thymine derivative (6) with a yield of $49 \%$. Deprotection of the silyl and benzoyl groups of 6 with tetra- $n$-butylammonium fluoride (TBAF) and $\mathrm{NH}_{4} \mathrm{OH}$ produced the thymine analog 3 with a yield of $80 \%$. The primary hydroxy group of 3 was protected with a 4,4'-dimethoxytrityl (DMTr) group to give a mono-DMTr derivative (7) with a yield of $99 \%$. Compound 7 was phosphitylated using the standard procedure, leading to the formation of the corresponding phosphoramidite (8) with a yield of $80 \%$.

In a similar manner, 2-bis(tert-butoxycarbonyl)amino-6chloropurine was coupled with the arylboronic acid derivative 5 in the presence of $\mathrm{Cu}(\mathrm{OAc})_{2}$ and pyridine in DMF to form an $N^{9}$-arylpurine derivative (9) with a yield of $31 \%$. The treatment of 9 with 2-mercaptoethanol and NaOMe in $\mathrm{MeOH}$ gave an $N^{9}$ arylguanine derivative (10) with a yield of $66 \%$. The silyl groups of $\mathbf{1 0}$ were removed by treatment with TBAF to give the guanosine analog 4 with a yield of $71 \%$. The exo-amino function of $\mathbf{1 0}$ was protected with a dimethylaminomethylene group to produce a fully protected guanosine derivative (11) with a yield of $83 \%$. After deprotection of the silyl groups with TBAF, the primary hydroxy group of $\mathbf{1 2}$ was protected with a DMTr group to obtain a mono-DMTr derivative (13) with a yield of $98 \%$. Compound 13 was phosphitylated by the standard procedure to lead to the formation of the corresponding phosphoramidite (14) with a yield of $96 \%$.

All oligonucleotides (ONs) containing the analogs 1-4 were synthesized using the phosphoramidites $\mathbf{8}$ and 14, and the phosphoramidites of the cytidine and adenosine analogs, which were synthesized using the previously published procedure. ${ }^{5 c}$ The ON sequences used are given in Table 1 . The ONs were analyzed by matrix-assisted laser desorption/ionization time-of-flight mass spectrometry (MALDI-TOF/MS), and the observed molecular weights obtained from these analyses were consistent with the ON structures.

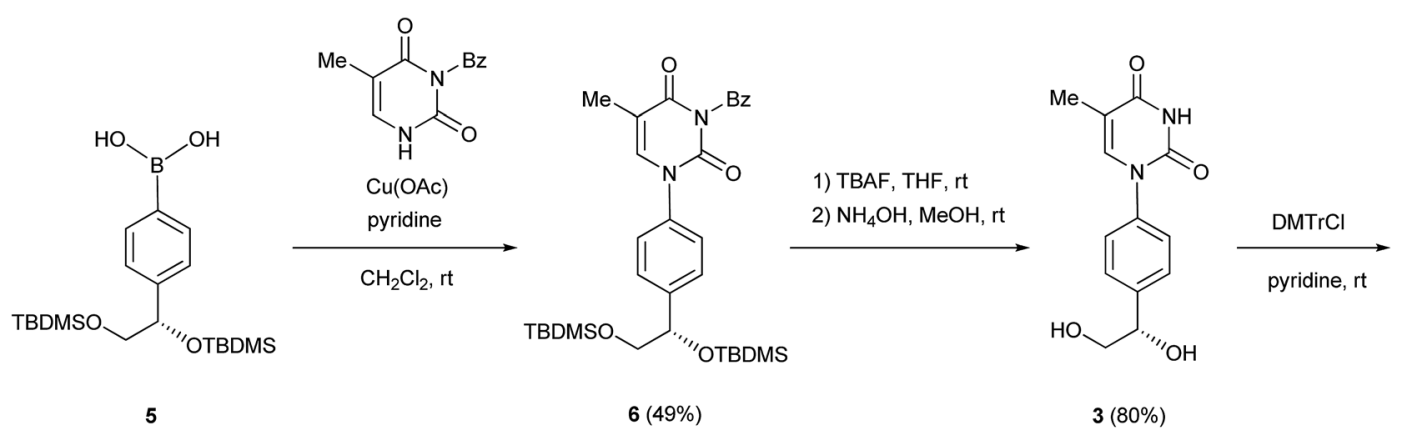<smiles>COCC(O)c1ccc(-n2cc(C)c(=O)[nH]c2=O)cc1</smiles>

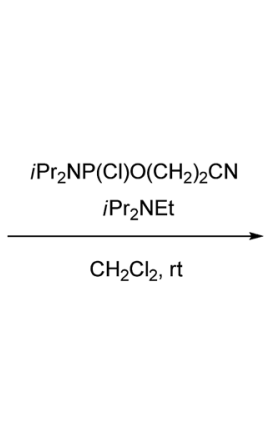<smiles>COC[C@H](OP(OCCC#N)N(C(C)C)C(C)C)c1ccc(-n2cc(O)c(=O)[nH]c2=O)cc1</smiles> 

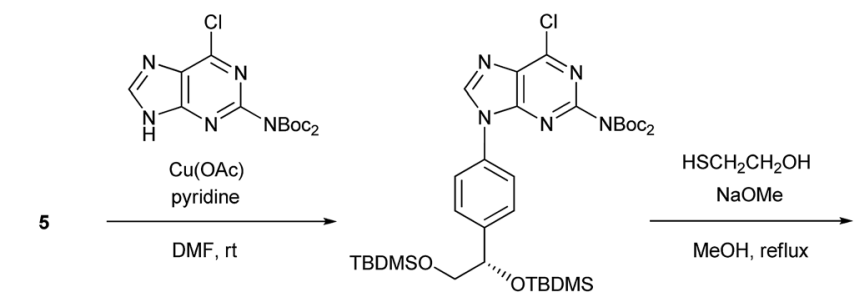<smiles>[R]OC(O)c1ccc(-n2cnc3c(=O)[nH]c(N)nc32)cc1</smiles>

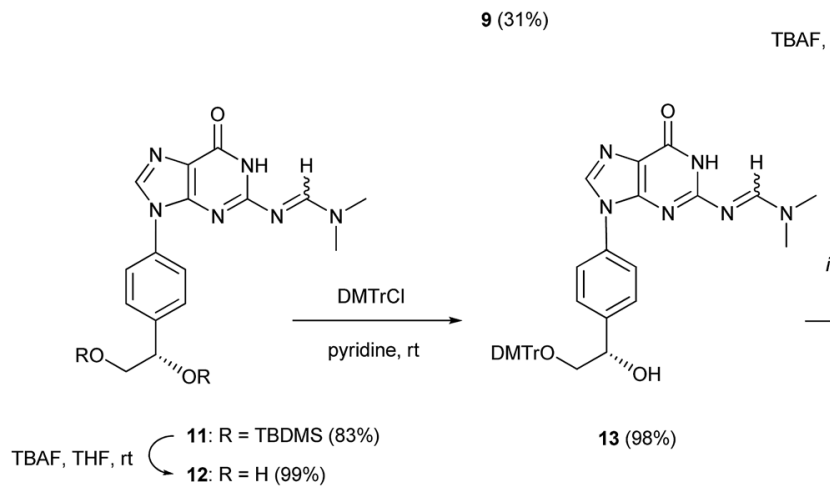

TBAF, THF, rt $\begin{aligned} \text { 10: } R=\operatorname{TBDMS}(66 \%) \\ 4: R=H(71 \%)\end{aligned}$
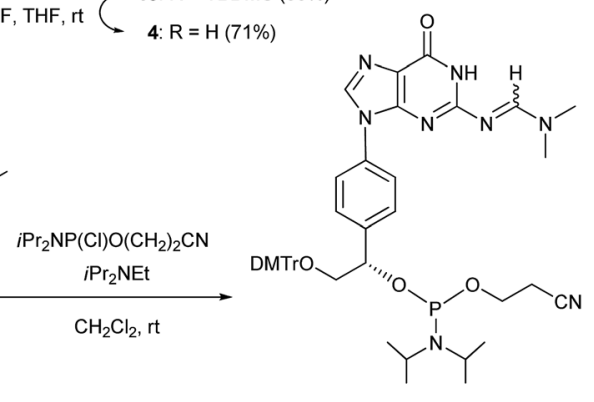

Scheme 2

Table 1 Sequences of duplexes and ONs, and $T_{\mathrm{m}} \mathrm{s}$ and thermodynamic parameters of the duplexes

\begin{tabular}{|c|c|c|c|c|c|c|c|}
\hline Duplex & ON & Sequences $^{a}$ & $T_{\mathrm{m}}\left({ }^{\circ} \mathrm{C}\right)$ & $\Delta T_{\mathrm{m}}\left({ }^{\circ} \mathrm{C}\right)$ & $\begin{array}{l}\Delta H^{\circ} \\
\left(\mathrm{kcal} \mathrm{mol}^{-1}\right)\end{array}$ & $\begin{array}{l}\Delta S^{\circ} \\
\left(\mathrm{cal} \mathrm{mol}^{-1} \mathrm{~K}^{-1}\right)\end{array}$ & $\Delta G_{310}^{\circ}\left(\mathrm{kcal} \mathrm{mol}^{-1}\right)$ \\
\hline Duplex 1 & $\begin{array}{l}\text { DNA } 1 \\
\text { RNA } 1\end{array}$ & $\begin{array}{l}5^{\prime}-\mathrm{d}(\text { AAAGTTCACTACTCAAA)-3' } \\
3^{\prime} \text {-r(UUUCAAGUGAUGAGUUU)-5' }\end{array}$ & 52.3 & & -98.4 & -275.2 & -13.1 \\
\hline Duplex 2 & $\begin{array}{l}\text { ON } 1 \\
\text { RNA } 1\end{array}$ & $\begin{array}{l}\left.5^{\prime} \text {-d(AA }{ }^{\mathbf{b}} \mathbf{A}^{\mathbf{b}} \text { GTTCACTACTCA } \mathbf{A}^{\mathbf{b}} \mathbf{A}^{\mathbf{b}} \mathbf{A}^{\mathbf{b}}\right)-3^{\prime} \\
3^{\prime} \text {-r(UUUCAAGUGUGAGUU)-5 }\end{array}$ & 55.6 & +3.3 & -94.7 & -259.8 & -14.1 \\
\hline Duplex 3 & $\begin{array}{l}\text { DNA } 2 \\
\text { RNA } 2\end{array}$ & $\begin{array}{l}5^{\prime}-\mathrm{d}\left(\text { ACAGTTCACTACTCACA)- } 3^{\prime}\right. \\
3^{\prime}-\mathrm{r}(\text { UGUCAAGUGAUGAGUGU)-5' }\end{array}$ & 58.0 & & -144.1 & -406.6 & -18.0 \\
\hline Duplex 4 & $\begin{array}{l}\text { ON } 2 \\
\text { RNA } 2\end{array}$ & $\begin{array}{l}5^{\prime}-\mathrm{d}\left(\mathbf{A C}^{\mathbf{b}} \mathbf{A}^{\mathbf{b}} \text { GTTCACTACTCA } \mathbf{A}^{\mathbf{b}} \mathbf{C}^{\mathbf{b}} \mathbf{A}^{\mathbf{b}}\right)-3^{\prime} \\
3^{\prime} \text {-r(UGUCAAGGAUGAGGU)-5 }\end{array}$ & 57.9 & -0.1 & -113.6 & -315.0 & -16.0 \\
\hline Duplex 5 & $\begin{array}{l}\text { DNA } 3 \\
\text { RNA } 3\end{array}$ & $\begin{array}{l}5^{\prime}-\mathrm{d}(\text { AGAGTTCACTACTCAGA)--3' } \\
3^{\prime}-\mathrm{r}(\text { UCUCAAGUGAUGAGUCU)-5' }\end{array}$ & 57.5 & & -132.5 & -373.5 & -16.8 \\
\hline Duplex 6 & $\begin{array}{l}\text { ON } 3 \\
\text { RNA } 3\end{array}$ & $\begin{array}{l}5^{\prime}-\mathrm{d}\left(\text { AG }^{\mathbf{b}} \mathbf{A}^{\mathbf{b}} \text { GTTCACTACTCA } \mathbf{A}^{\mathbf{b}} \mathbf{G}^{\mathbf{b}} \mathbf{A}^{\mathbf{b}}\right)-3^{\prime} \\
3^{\prime} \text {-r(UCUCAAGUGAUGAGUCU)-5' }\end{array}$ & 56.4 & -1.1 & -112.3 & -313.0 & -15.3 \\
\hline Duplex 7 & $\begin{array}{l}\text { DNA } 4 \\
\text { RNA } 4\end{array}$ & $\begin{array}{l}5^{\prime} \text {-d(ATAGTTCACTACTCATA)--3' } \\
3^{\prime} \text {-r(UAUCAAGUGAUGAGUAU)-5' }\end{array}$ & 54.8 & & -122.0 & -343.9 & -15.4 \\
\hline Duplex 8 & $\begin{array}{l}\text { ON } 4 \\
\text { RNA } 4\end{array}$ & $\begin{array}{l}\left.5^{\prime} \text {-d(AT }{ }^{\mathbf{b}} \mathbf{A}^{\mathbf{b}} \text { GTTCACTACTCA }{ }^{\mathbf{b}} \mathbf{T}^{\mathbf{b}} \mathbf{A}^{\mathbf{b}}\right)-3^{\prime} \\
3^{\prime} \text {-r(UAUCAAGUGAUGAGUAU)-5' }\end{array}$ & 56.0 & +1.2 & -117.6 & -329.6 & -15.5 \\
\hline Duplex 9 & $\begin{array}{l}\text { DNA } 5 \\
\text { RNA } 5\end{array}$ & $\begin{array}{l}5^{\prime}-\mathrm{d}\left(\text { AAATCACTACAAA) }-3^{\prime}\right. \\
3^{\prime}-\mathrm{r}\left(\text { UUUAGUGAUGUUU) }-5^{\prime}\right.\end{array}$ & 36.8 & & -89.6 & -260.9 & -8.7 \\
\hline Duplex 10 & $\begin{array}{l}\text { ON } 5 \\
\text { RNA } 5\end{array}$ & $\begin{array}{l}5^{\prime}-\mathrm{d}\left(\text { AA }^{\mathbf{b}} \mathbf{A}^{\mathbf{b}} \text { TCACTACA }\right. \\
\left.3^{\prime} \text {-r(UUUAG } \mathbf{A}^{\mathbf{b}} \mathbf{A}^{\mathbf{b}}\right)-3^{\prime} \\
\text { (U)UUUUU })-5^{\prime}\end{array}$ & 35.0 & -1.8 & -66.0 & -186.1 & -8.4 \\
\hline Duplex 11 & $\begin{array}{l}\text { DNA } 6 \\
\text { RNA } 6\end{array}$ & $\begin{array}{l}5^{\prime}-\mathrm{d}(\text { ACATCACTACACA)-3' } \\
3^{\prime}-\mathrm{r}(\text { UGUAGUGAUGUGU)-5' }\end{array}$ & 47.7 & & -108.6 & -310.5 & -12.4 \\
\hline Duplex 12 & $\begin{array}{l}\text { ON } 6 \\
\text { RNA } 6 \\
\text { DNA } 7 \\
\text { ON } 7 \\
\text { RNA } 7 \\
\text { RNA } 8\end{array}$ & 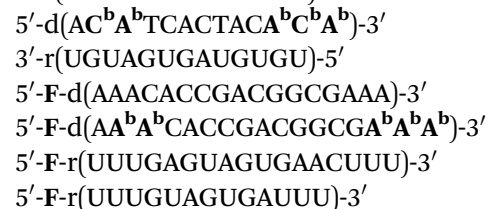 & 41.8 & -5.9 & -99.9 & -288.8 & -10.4 \\
\hline
\end{tabular}

${ }^{a} \mathrm{~F}$ indicates a fluorescein. 


\section{Thermal and thermodynamic stabilities of duplexes}

The thermal stabilities of DNA/RNA and ON/RNA duplexes containing the analogs were compared by measuring their melting temperatures $\left(T_{\mathrm{m}} \mathrm{s}\right)$ in a $10 \mathrm{mM}$ sodium phosphate buffer (pH 7.0) containing $100 \mathrm{mM} \mathrm{NaCl}$ (Table 1 and Fig. S1 $\dagger$ ). Furthermore, to examine the stability of the duplexes in detail, we calculated the thermodynamic parameters of duplex formation based on the slope of the plot of $1 / T_{\mathrm{m}} v s \cdot \ln \left(C_{\mathrm{T}} / 4\right)$, where $C_{\mathrm{T}}$ is the total concentration of single-stranded $\mathrm{ON}$ and RNA (Table 1 and Fig. S3†). Duplexes 1-8 are composed of 17 base pairs, while duplexes 9-12 comprise 13 base pairs. All ON/ RNA duplexes contain two and three analogs at the $5^{\prime}$ - and $3^{\prime}$ regions of the ONs, respectively. Duplex 2 has five $A^{\mathrm{b}}: \mathrm{rU}$ base pairs among its 17 base pairs, whereas duplexes 4,6 , and 8 contain two $\mathrm{C}^{\mathrm{b}}: \mathrm{rG}, \mathrm{G}^{\mathrm{b}}: \mathrm{rC}$, and $\mathrm{T}^{\mathrm{b}}$ :rA base pairs in addition to the $\mathrm{A}^{\mathrm{b}}$ :rU base pairs in the sequences, respectively. Duplex 10 has five $A^{b}$ :rU base pairs among its 13 base pairs, while duplex 12 contains two $\mathrm{C}^{\mathrm{b}}$ :rG base pairs in addition to the $\mathrm{A}^{\mathrm{b}}: \mathrm{rU}$ base pairs in the sequence.

The thermal and thermodynamic stabilities of the duplexes containing the analogs were found to be dependent on their sequences. Duplexes 2 and 8 , containing the $\mathrm{A}^{\mathrm{b}}: \mathrm{rU}$ and $\mathrm{T}^{\mathrm{b}}$ :rA base pairs, were thermally and thermodynamically more stable than the corresponding DNA/RNA duplexes 1 and 7 , respectively, while duplexes 4 and 6 , containing the $\mathrm{C}^{\mathrm{b}}$ :rG and $\mathrm{G}^{\mathrm{b}}$ :rC base pairs, were thermally and thermodynamically less stable than the corresponding DNA/RNA duplexes 3 and 5, respectively. However, the differences in the thermal and thermodynamic stabilities between the duplexes containing the analogs and the unmodified DNA/RNA duplexes were not large $\left(\Delta T_{\mathrm{m}}=-1.1 \sim+3.3{ }^{\circ} \mathrm{C}, \Delta \Delta G_{310}^{\circ}=+2.0 \sim-1.0 \mathrm{kcal}\right.$ $\left.\mathrm{mol}^{-1}\right)$. On comparison of the thermodynamic parameters, it was found that duplex formation between ONs containing the analogs and the complementary RNAs was less favorable in terms of enthalpy but more favorable in terms of entropy than that of the corresponding unmodified DNA/RNA duplexes.

The $\Delta T_{\mathrm{m}}$ and $\Delta \Delta G_{310}^{\circ}$ values between duplexes 1 and 2 were $+3.3{ }^{\circ} \mathrm{C}$ and $-1.0 \mathrm{kcal} \mathrm{mol}^{-1}$, respectively, while those between duplexes 9 and 10 were $-1.8{ }^{\circ} \mathrm{C}$ and $+0.3 \mathrm{kcal} \mathrm{mol}^{-1}$, respectively. Similarly, the $\Delta T_{\mathrm{m}}$ and $\Delta \Delta G_{310}^{\circ}$ values between duplexes 3 and 4 were $-0.1{ }^{\circ} \mathrm{C}$ and $+2.0 \mathrm{kcal} \mathrm{mol}^{-1}$, respectively, while those between duplexes 11 and 12 were $-5.9{ }^{\circ} \mathrm{C}$ and $+2.0 \mathrm{kcal}$ $\mathrm{mol}^{-1}$, respectively. Thus, incorporation of the analogs into duplexes comprising 13 base pairs destabilized the duplexes more than their incorporation into duplexes composed of 17 base pairs, both thermally and thermodynamically.

The base-discriminating abilities of the analogs 1-4 in DNA/ RNA duplexes were then assessed (Fig. 2 and Table S1 $\dagger$ ). The $\Delta T_{\mathrm{m}}\left(T_{\mathrm{m}}\right.$ of duplex containing mismatched base pair $-T_{\mathrm{m}}$ of complementary duplex) values for the unmodified duplexes were $-0.6 \sim-12.3{ }^{\circ} \mathrm{C}$, whereas those for the duplexes containing the analogs were $-0.3 \sim-5.2{ }^{\circ} \mathrm{C}$. Thus, the analogs 1-4 have base-discriminating abilities in DNA/RNA duplexes, though weaker than those of the corresponding unmodified nucleosides.
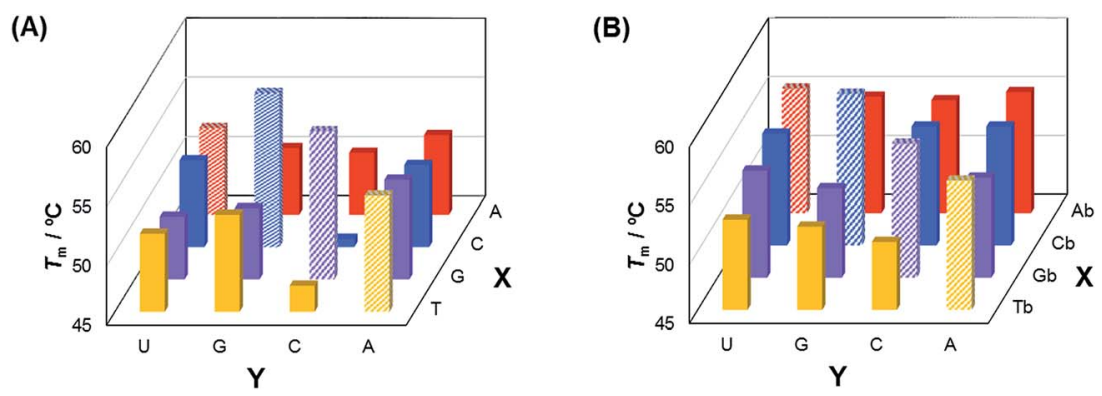

Fig. 2 Comparison of the $T_{m}$ values of the duplexes composed of matched and mismatched sequences. Sequences are shown in Table S1. $\dagger$

(A)

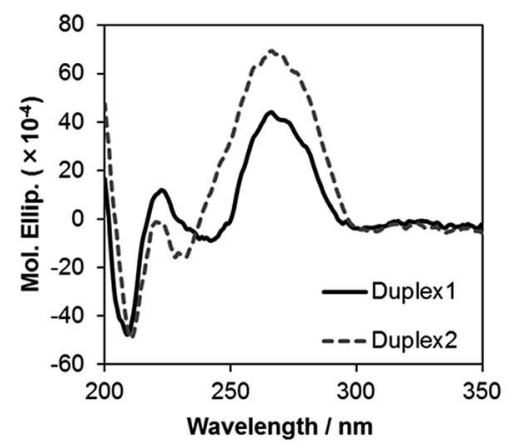

(B)

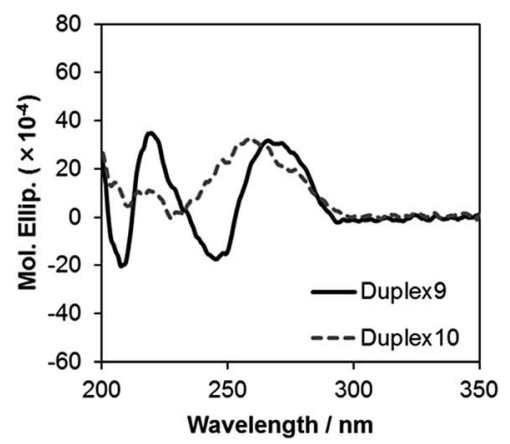

Fig. $3 \mathrm{CD}$ spectra of duplexes in a buffer of $10 \mathrm{mM}$ sodium phosphate $(\mathrm{pH} 7.0)$ and $0.1 \mathrm{M} \mathrm{NaCl}$ at $15^{\circ} \mathrm{C}$. Concentration of duplexes: $4 \mu \mathrm{M}$. 


\section{Circular dichroism}

To study the global conformations of the duplexes, we analyzed the circular dichroism (CD) spectra of the duplexes composed of ON 1 (17-mer) and of ON 5 (13-mer), containing five analogs (Fig. 3). The ON 1/RNA 1 duplex showed a positive CD band around $270 \mathrm{~nm}$ and a negative $\mathrm{CD}$ band at $210 \mathrm{~nm}$, which was similar to the spectrum of the unmodified DNA 1/RNA 1 duplex, whereas the shape of the CD spectrum of the ON 5/RNA 5 duplex was different from that of the unmodified DNA 5/RNA 5 duplex. These results suggest that the global conformation of the ON 1 / RNA 1 duplex composed of 17 base pairs is similar to that of the unmodified DNA 1/RNA 1 duplex, while the global conformation of the ON 5/RNA 5 duplex comprising 13 base pairs is different from that of the unmodified DNA 5/RNA 5 duplex.

\section{Nuclease resistance}

Previously, we reported that BGNA-DNA chimeras are more resistant to hydrolysis by a snake venom phosphodiesterase (a $3^{\prime}$-exonuclease) than unmodified DNA. ${ }^{5 c}$ To be able to function as drugs, AONs must be stable in blood, which contains various enzymes, including nucleases. Therefore, we investigated the stability of BGNADNA chimeras in bovine serum (BS). DNA 7 or ON 7, labeled with fluorescein at the $5^{\prime}$-end, was incubated in a buffer containing $30 \%$ BS and analyzed by polyacrylamide gel electrophoresis under denaturing conditions (Fig. 4). The halflife of DNA 7 was $35 \mathrm{~min}$, while that of ON 7 was $11.7 \mathrm{~h}$. Thus, the BGNA-DNA chimera (ON 7) was approximately 20-fold more stable in the buffer containing $30 \%$ BS than the unmodified DNA 7.
(A)

DNA7

F-5'-d(AAACACCGACGGCGAAA)-3'

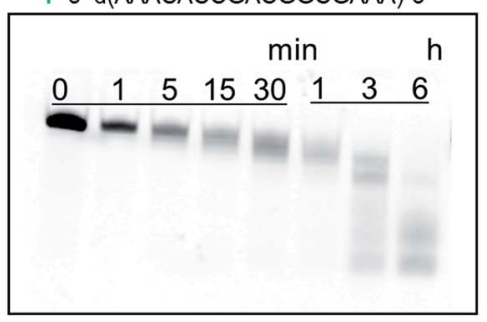

(B)

ON7

F-5'-d $\left(A A^{b} A^{b} C A C C G A C G G C G A^{b} A^{b} A^{b}\right)-3^{\prime}$

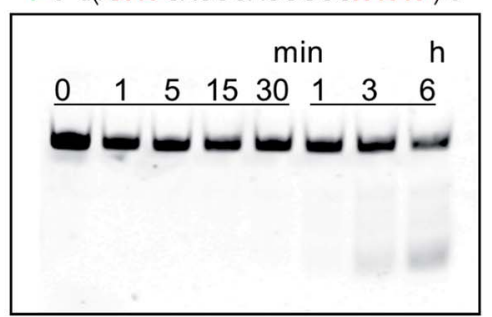

Fig. 4 Polyacrylamide gel electrophoresis of (A) DNA 7 and (B) ON 7 treated in a buffer containing 30\% BS. F denotes a fluorescein. Experimental conditions are described in the Experimental.

(A)

DNA1/RNA7

5'-d(AAAGTTCACTACTCAAA)-3' 3'-r(UUUCAAGUGAUGAGUUU)-5'-F

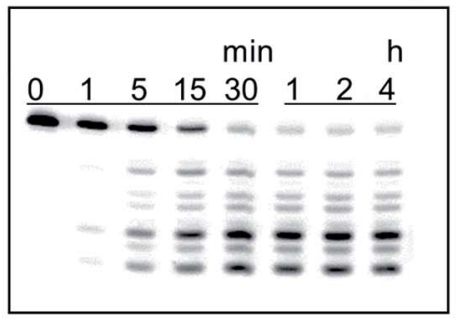

(C)

DNA7/RNA12

5'-d(AAATCACTACAAA)-3'

3'-r(UUUAGUGAUGUUU)-5'-F

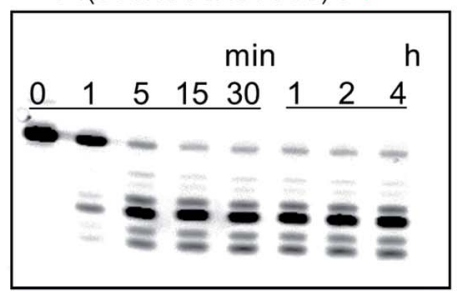

(B)

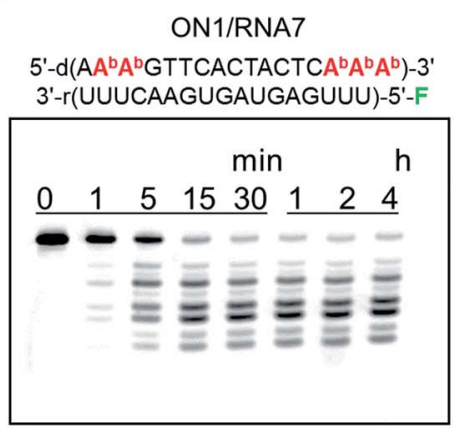

(D)

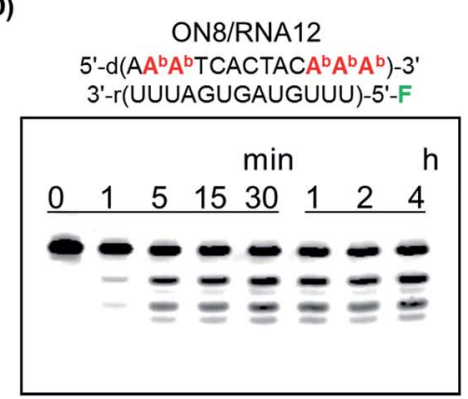

Fig. 5 Polyacrylamide gel electrophoresis of (A) DNA 1/RNA 7 duplex, (B) ON 1/RNA 7 duplex, (C) DNA 7/RNA 12 duplex, and (D) ON 8/RNA 12 duplex hydrolyzed by human recombinant RNase H1. F denotes a fluorescein. Experimental conditions are described in the Experimental. 


\section{Degradation by human recombinant RNase H1}

To function as therapeutics, AONs need to elicit RNase $\mathrm{H}$ activity in human cells. We previously reported that a duplex between a BGNA-DNA chimera and a complementary RNA could act as a substrate for Escherichia coli RNase H. $^{5 c}$ In this study, we examined cleavage of RNAs by human recombinant RNase H1. A DNA fragment of $E$. coli mal $E$ gene encoding maltose binding protein (MBP) and a fragment encoding catalytic domain of human RNase H1 (residues 136-286, H-domain) were subcloned into the multiple cloning site of pET15b, resulting in pET-MBP-hRNase $\mathrm{H} 1$ (H-domain) vector for expressing MBP-hRNase H1 (H-domain) fusion protein. Human recombinant RNase $\mathrm{H} 1$ was expressed from the pET-MBPhRNase H1 (H-domain) vector in E. coli BL21(DE3) competent cells. The duplex between DNA 1 or ON 1 and RNA 7, labeled with fluorescein at the $5^{\prime}$-end, or DNA 5 or ON 5 and RNA 8, also labeled with fluorescein at the $5^{\prime}$-end, was incubated in a buffer containing human recombinant RNase $\mathrm{H}$, and the products were analyzed by polyacrylamide gel electrophoresis under denaturing conditions (Fig. 5). The initial rates of degradation of the DNA 1/RNA 7 and ON 1/RNA 7 duplexes (17-mers) were $206 \mathrm{pmol} \mathrm{min}^{-1}$ and $215 \mathrm{pmol} \mathrm{min}^{-1}$, respectively, while those of the DNA 5/RNA 8 and ON 5/RNA 8 duplexes (13-mers) were

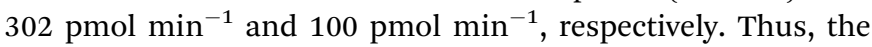
ability of ON 5 (13-mer) containing five analogs to elicit human RNase $\mathrm{H}$ activity was found to be weaker than that of the unmodified DNA 5, while the ability of the ON 1 (17-mer) containing five analogs to elicit human RNase $\mathrm{H}$ activity was comparable with that of the unmodified DNA 1.

X-ray co-crystal structural analysis has shown that human RNase $\mathrm{H}$ recognizes eight base-pairs in a DNA/RNA duplex. ${ }^{8}$ ON 1 contains eleven contiguous unmodified nucleoside residues, while ON 5 has seven consecutive unmodified nucleoside moieties. This may partially explain why the ON 5/RNA duplex is a poor substrate for human RNase H. Furthermore, CD spectra suggested that the global conformation of the ON 1/RNA duplex was similar to that of the unmodified DNA/RNA duplex, while the global conformation of the ON 5/RNA duplex was different from that of the unmodified DNA/RNA duplex. This is also likely to influence the abilities of the ONs to elicit human RNase H activity.

\section{Conclusions}

We have synthesized nucleoside analogs with a thymine- or guanine-benzene-glycol structure. We have synthesized DNAs incorporating four nucleoside analogs - thymidine, cytidine, adenosine, and guanosine - at the $5^{\prime}$ - and $3^{\prime}$-regions of the DNAs. We found that the benzene-glycol nucleic acid (BGNA)DNA chimeras formed thermally and thermodynamically stable duplexes with complementary RNAs, and these are more stable in bovine serum than unmodified DNA. Furthermore, we found that duplexes formed by BGNA-DNA chimeras and complementary RNAs are good substrates for human RNase H. Based on these results, we believe that BGNA-DNA chimeras are good candidates for the development of therapeutic antisense molecules.

\section{Experimental}

\section{General remarks}

The chemicals were purchased from Sigma-Aldrich, Kanto Chemical Co. Inc., Tokyo Chemical Industry Co., Ltd., Nacalai Tesque Inc., Wako Pure Chemical Industries, Ltd., and Glen Research Co. All chemicals were used without further purification. Gibco ${ }^{\circledR}$ bovine serum was purchased from Thermo Fisher Scientific Inc. A pET15b expression vector was purchased from Novagen, Merck Millipore, Japan. E. coli BL21(DE3) competent cells were purchased from NEW ENGLAND BioLabs ${ }^{\circledR}$ Japan Inc. $\mathrm{CDCl}_{3}$ (CIL) or DMSO- $d_{6}$ (CIL) was used as a solvent for obtaining NMR spectra. Chemical shifts $(\delta)$ are given in parts per million (ppm) downfield from $\left(\mathrm{CH}_{3}\right)_{4} \mathrm{Si}\left(\delta 0.00\right.$ for ${ }^{1} \mathrm{H}$ NMR in $\mathrm{CDCl}_{3}$ ), or a solvent (for ${ }^{13} \mathrm{C} \mathrm{NMR}$ and ${ }^{1} \mathrm{H}$ NMR in DMSO- $d_{6}$ ) as an internal reference with coupling constants $(J)$ in $\mathrm{Hz}$. The abbreviations s, d, and q signify singlet, doublet, and quartet, respectively.

$(S)$ - $N^{3}$-Benzoyl-1-\{4-[1,2-bis(tert-butyldimethylsilyloxy)ethyl] phenyl\}thymine (6). To a mixture of $(S)$-4-[1,2-bis(tert-butyldimethylsilyloxy)ethyl]phenylboronic acid (5) (0.56 g, $1.35 \mathrm{mmol})$ in $\mathrm{CH}_{2} \mathrm{Cl}_{2}(5 \mathrm{~mL})$ was added $\mathrm{Cu}(\mathrm{OAc})_{2}(0.25 \mathrm{~g}, 1.35 \mathrm{mmol}, 1$ eq.), $N^{3}$-benzoylthymine ( $0.62 \mathrm{~g}, 2.71 \mathrm{mmol}, 2 \mathrm{eq}$.), and pyridine ( 0.21 $\mathrm{mL}, 2.71 \mathrm{mmol}, 2$ eq.). The mixture was vigorously stirred at room temperature for $30 \mathrm{~min}$. The resulting mixture was filtered through a Celite pad, and the eluent was partitioned between $\mathrm{CHCl}_{3}$ and brine. The organic layer was dried $\left(\mathrm{Na}_{2} \mathrm{SO}_{4}\right)$, and concentrated. The residue was purified by column chromatography $\left(\mathrm{SiO}_{2}, 20 \%\right.$ EtOAc in hexane) to give $6(0.39 \mathrm{~g}, 0.65 \mathrm{mmol}$, 49\%): ${ }^{1} \mathrm{H}$ NMR (600 MHz, $\mathrm{CDCl}_{3}$ ): $\delta=-0.05$ to $-0.03(\mathrm{~m}, 9 \mathrm{H})$, 0.07 (s, 3H), 0.85 (s, 9H), $0.88(\mathrm{~s}, 9 \mathrm{H}), 2.02(\mathrm{~d}, J=1.4 \mathrm{~Hz}, 3 \mathrm{H})$, $3.51(\mathrm{dd}, J=4.8$ and $10.2,1 \mathrm{H}), 3.64(\mathrm{dd}, J=6.9$ and $10.3,1 \mathrm{H})$, $4.72(\mathrm{t}, J=5.8,1 \mathrm{H}), 7.29(\mathrm{~s}, 1 \mathrm{H}), 7.32(\mathrm{~d}, J=8.9,2 \mathrm{H}), 7.45(\mathrm{~d}, J=$ $8.2,2 \mathrm{H}), 7.50(\mathrm{t}, J=7.9,2 \mathrm{H}), 7.64(\mathrm{t}, J=6.8,1 \mathrm{H}), 7.98(\mathrm{~d}, J=6.8$, 2H). $\left.{ }^{13} \mathrm{C} \mathrm{NMR} \mathrm{(151} \mathrm{MHz,} \mathrm{CDCl}_{3}\right): \delta=-5.6,-5.5,-4.9,-4.8$, 12.4, 18.2 , 18.4, 25, 8, 25.9, 69.7, 75.3, 111.1, 125.7, 127.5, 129.1, 130.5 , 131.7, 134.9, 137.2, 140.5, 143.8, 149.3, 163.2, 168.9. HRMS (ESI): calcd for $\mathrm{C}_{32} \mathrm{H}_{46} \mathrm{~N}_{2} \mathrm{O}_{5} \mathrm{Si}_{2}, 633.2582[\mathrm{M}+\mathrm{K}]^{+}$, found 633.2600 .

(S)-1-[4-(1,2-Dihydroxyethyl)phenyl]thymine (3). Compound $6(0.51 \mathrm{~g}, 0.86 \mathrm{mmol})$ was dissolved in THF $(5 \mathrm{~mL})$. TBAF $(1 \mathrm{M}$ in THF, $2.58 \mathrm{~mL}$ ) was added to the solution, and the mixture was stirred at room temperature for $16 \mathrm{~h}$. The solvent was evaporated in vacuo, and the resulting residue was dissolved in $\mathrm{MeOH}$ $(5 \mathrm{~mL})$. Concentrated $\mathrm{NH}_{4} \mathrm{OH}(15 \mathrm{~mL})$ was added to the solution, and the mixture was stirred at room temperature for $4 \mathrm{~h}$. The solvent was evaporated in vacuo, and the resulting residue was purified by column chromatography $\left(\mathrm{SiO}_{2}, 5-10 \% \mathrm{MeOH}\right.$ in $\left.\mathrm{CHCl}_{3}\right)$ to give $3(0.18 \mathrm{~g}, 0.69 \mathrm{mmol}, 80 \%):{ }^{1} \mathrm{H} \mathrm{NMR}(600 \mathrm{MHz}$, DMSO- $\left.d_{6}\right): \delta=3.19(\mathrm{~s}, 1 \mathrm{H}), 4.02(\mathrm{~s}, 1 \mathrm{H}), 4.13$ to $4.15(\mathrm{~m}, 3 \mathrm{H})$, $5.27(\mathrm{dd}, J=5.5$ and $10.3,1 \mathrm{H}), 5.46(\mathrm{t}, J=5.9,1 \mathrm{H}), 6.02(\mathrm{~d}, J=$ $4.1,1 \mathrm{H}), 8.03(\mathrm{~d}, J=8.2,2 \mathrm{H}), 8.12(\mathrm{~d}, J=8.2,2 \mathrm{H}), 8.28(\mathrm{~s}, 1 \mathrm{H})$, $12.09(\mathrm{~s}, 1 \mathrm{H}) .{ }^{13} \mathrm{C}$ NMR $\left(151 \mathrm{MHz}, \mathrm{DMSO}-d_{6}\right): \delta=11.8,67.3,73.3$, 109.2, 126.2, 126.9, 137.6, 141.4, 143.4, 150.4, 164.3. HRMS (ESI): calcd for $\mathrm{C}_{13} \mathrm{H}_{14} \mathrm{~N}_{2} \mathrm{O}_{4}, 263.1032[\mathrm{M}+\mathrm{H}]^{+}$, found 263.1049. 
(S)-1-\{4-[2-(4,4'-Dimethoxytrityloxy)-1-hydroxyethyl]phenyl\} thymine (7). A mixture of $3(0.15 \mathrm{~g}, 0.57 \mathrm{mmol})$ and DMTrCl $(0.21 \mathrm{~g}, 0.63 \mathrm{mmol}, 1.1 \mathrm{eq}$.) in pyridine $(1.5 \mathrm{~mL})$ was stirred at room temperature for $90 \mathrm{~min}$. The mixture was partitioned between EtOAc and aqueous $\mathrm{NaHCO}_{3}$ (saturated). The organic layer was washed with brine, dried $\left(\mathrm{Na}_{2} \mathrm{SO}_{4}\right)$, and concentrated. The residue was purified by column chromatography $\left(\mathrm{SiO}_{2}, 66 \%\right.$ EtOAc in hexane) to give 7 ( $0.32 \mathrm{~g}, 0.56 \mathrm{mmol}, 99 \%):{ }^{1} \mathrm{H} \mathrm{NMR}$ $\left(600 \mathrm{MHz}, \mathrm{CDCl}_{3}\right): \delta=1.94(\mathrm{~s}, 3 \mathrm{H}), 2.92(\mathrm{~s}, 1 \mathrm{H}), 3.23(\mathrm{t}, J=9.3$, $1 \mathrm{H}), 3.34(\mathrm{dd}, J=3.4$ and 9.6, $1 \mathrm{H}), 3.78(\mathrm{~s}, 6 \mathrm{H}), 4.81(\mathrm{dd}, J=3.4$ and $8.3,1 \mathrm{H}), 6.82(\mathrm{~d}, J=8.2,4 \mathrm{H}), 7.11(\mathrm{~d}, J=1.4,1 \mathrm{H}), 7.21$ to $7.29(\mathrm{~m}, 9 \mathrm{H}), 7.36$ to $7.41(\mathrm{~m}, 4 \mathrm{H}), 8.46(\mathrm{~s}, 1 \mathrm{H}) .{ }^{13} \mathrm{C}$ NMR $(151$ $\left.\mathrm{MHz}, \mathrm{CDCl}_{3}\right): \delta=12.3,55.2,69.0,72.7,86.7,111.1,113.2,126.1$, 126.9, 127.4, 127.9, 128.0, 130.0, 135.7, 137.8, 140.6, 141.4, 144.6, 150.0, 158.6, 163.7. HRMS (ESI): calcd for $\mathrm{C}_{34} \mathrm{H}_{32} \mathrm{~N}_{2} \mathrm{O}_{6}$, $587.2158[\mathrm{M}+\mathrm{Na}]^{+}$, found 587.2160 .

(S)-1-(4-\{1-[(2-Cyanoethoxy)( $N, N$-diisopropylamino)phosphanyloxy]-2-(4,4'-dimethoxytrityloxy)ethyl $\}$ phenyl)thymine

Compound $7(0.63 \mathrm{~g}, 1.10 \mathrm{mmol})$ was dissolved in $\mathrm{CH}_{2} \mathrm{Cl}_{2}(6 \mathrm{~mL})$ containing $N, N$-diisopropylethylamine $(0.57 \mathrm{~mL}, 3.32 \mathrm{mmol}, 3$ eq.). Chloro(2-cyanoethoxy)( $N, N$-diisopropylamino)phosphine $(0.37 \mathrm{~mL}, 1.66 \mathrm{mmol}, 1.5 \mathrm{eq}$.) was added to the solution, and the mixture was stirred at room temperature for $1 \mathrm{~h}$. Aqueous $\mathrm{NaHCO}_{3}$ (saturated) and $\mathrm{CHCl}_{3}$ were added to the mixture, and the separated organic layer was washed with aqueous $\mathrm{NaHCO}_{3}$ (saturated) and brine, dried $\left(\mathrm{Na}_{2} \mathrm{SO}_{4}\right)$ and concentrated. The residue was purified by column chromatograph (a neutralized $\mathrm{SiO}_{2}, 80 \%$ EtOAc in hexane) to give $8(0.67 \mathrm{~g}, 0.87 \mathrm{mmol}, 80 \%)$ : ${ }^{31} \mathrm{P}$ NMR (162 MHz, $\left.\mathrm{CDCl}_{3}\right): \delta=149.6,150.2$. HRMS (ESI): calcd for $\mathrm{C}_{43} \mathrm{H}_{49} \mathrm{~N}_{4} \mathrm{O}_{7} \mathrm{P}, 765.3417[\mathrm{M}+\mathrm{H}]^{+}$, found 765.3423.

(S)-2-[N,N-Bis(tert-butoxycarbonyl)amino]-6-chloro-9-\{4-[1,2bis(tert-butyldimethylsilyloxy)ethyl]phenyl\}purine (9). To a mixture of 2-[N,N-bis(tert-butoxycarbonyl)amino]-6chloropurine $(2.06 \mathrm{~g}, 5.58 \mathrm{mmol})$ and $5(2.29 \mathrm{~g}, 5.58 \mathrm{mmol})$ in DMF $(23 \mathrm{~mL})$ was added $\mathrm{Cu}(\mathrm{OAc})_{2}(2.03 \mathrm{~g}, 11.16 \mathrm{mmol}, 2$ eq. $)$ and pyridine $(0.9 \mathrm{~mL}, 11.16 \mathrm{mmol}, 2$ eq.). The mixture was vigorously stirred at room temperature for $63 \mathrm{~h}$. The resulting mixture was partitioned between EtOAc and brine. The organic layer was dried $\left(\mathrm{Na}_{2} \mathrm{SO}_{4}\right)$, and concentrated. The residue was purified by column chromatography $\left(\mathrm{SiO}_{2}, 20 \%\right.$ EtOAc in hexane) to give $9(1.28 \mathrm{~g}, 1.74 \mathrm{mmol}, 31 \%):{ }^{1} \mathrm{H}$ NMR (600 MHz, $\left.\mathrm{CDCl}_{3}\right): \delta=-0.03(\mathrm{~s}, 3 \mathrm{H}),-0.01(\mathrm{~s}, 6 \mathrm{H}), 0.10(\mathrm{~s}, 3 \mathrm{H}), 0.86(\mathrm{~s}$, $9 \mathrm{H}), 0.91(\mathrm{~s}, 9 \mathrm{H}), 1.44(\mathrm{~s}, 18 \mathrm{H}), 3.55(\mathrm{dd}, J=5.5$ and $10.3,1 \mathrm{H})$, $3.70(\mathrm{dd}, J=6.8$ and $10.3,1 \mathrm{H}), 4.77(\mathrm{t}, J=6.2,1 \mathrm{H}), 7.56(\mathrm{~d}, J=$ 8.9, 2H), $7.65(\mathrm{~d}, J=8.2,2 \mathrm{H}), 8.41(\mathrm{~s}, 1 \mathrm{H}) .{ }^{13} \mathrm{C} \mathrm{NMR}(151 \mathrm{MHz}$, $\left.\mathrm{CDCl}_{3}\right): \delta=-5.5,-5.4,-4.8,-4.7,18.3,18.4,25.8,25.9,27.9$, 69.6, 75.2, 83.6, 122.8, 128.0, 130.4, 132.8, 144.0, 144.7, 150.6, 151.7, 152.1, 152.6. HRMS (ESI): calcd for $\mathrm{C}_{35} \mathrm{H}_{56} \mathrm{ClN}_{5} \mathrm{O}_{6} \mathrm{Si}_{2}$, $734.3536[\mathrm{M}+\mathrm{H}]^{+}$, found 734.3570 .

(S)-9-\{4-[1,2-Bis(tert-butyldimethylsilyloxy)ethyl]phenyl\} guanine (10). A mixture of NaOMe (5 $\mathrm{M}$ in $\mathrm{MeOH}, 2.58 \mathrm{~mL}$ ) and 2-mercaptoethanol (1.22 $\mathrm{mL}, 17.56 \mathrm{mmol}, 10$ eq.) was added to a solution of $9(1.29 \mathrm{~g}, 1.75 \mathrm{mmol})$ in $\mathrm{MeOH}(26 \mathrm{~mL})$. The mixture was refluxed for $26 \mathrm{~h}$. The mixture was cooled and neutralized by $\mathrm{CH}_{3} \mathrm{CO}_{2} \mathrm{H}$. The resulting mixture was partitioned between $\mathrm{CHCl}_{3}$ and brine. The organic layer was dried $\left(\mathrm{Na}_{2} \mathrm{SO}_{4}\right)$, and concentrated. The residue was purified by column chromatography $\left(\mathrm{SiO}_{2}, 6 \% \mathrm{MeOH}\right.$ in $\left.\mathrm{CHCl}_{3}\right)$ to give $\mathbf{1 0}(0.59 \mathrm{~g}$, $1.15 \mathrm{mmol}, 66 \%):{ }^{1} \mathrm{H}$ NMR $\left(600 \mathrm{MHz}, \mathrm{CDCl}_{3}\right): \delta=-0.01(\mathrm{~s}, 6 \mathrm{H})$, $0.01(\mathrm{~s}, 3 \mathrm{H}), 0.10(\mathrm{~s}, 3 \mathrm{H}), 0.87(\mathrm{~s}, 9 \mathrm{H}), 0.91(\mathrm{~s}, 9 \mathrm{H}), 3.56(\mathrm{dd}, J=$ 5.5 and $10.3,1 \mathrm{H}), 3.66(\mathrm{dd}, J=7.6$ and $9.7,1 \mathrm{H}), 3.76(\mathrm{t}, J=6.2$, $1 \mathrm{H}), 6.56(\mathrm{~s}, 2 \mathrm{H}), 7.48(\mathrm{~d}, J=8.2,2 \mathrm{H}), 7.56(\mathrm{~d}, J=8.3,2 \mathrm{H}), 7.75$ (s, 1H), 12.32 (s, 1H). ${ }^{13} \mathrm{C}$ NMR (151 MHz, $\left.\mathrm{CDCl}_{3}\right): \delta=-5.5$, $-5.3,-4.8,-4.7,18.3,18.4,25.9,26.0,69.8,75.4,117.6,123.0$, 127.5, 133.8, 136.7, 142.7, 151.4, 154.0, 159.4. HRMS (ESI): calcd for $\mathrm{C}_{25} \mathrm{H}_{41} \mathrm{~N}_{5} \mathrm{O}_{3} \mathrm{Si}_{2}, 516.2826[\mathrm{M}+\mathrm{H}]^{+}$, found 516.2852.

(S)-9-[4-(1,2-Dihydroxyethyl)phenyl]guanine (4). Compound $10(0.47 \mathrm{~g}, 0.91 \mathrm{mmol})$ was dissolved in THF $(5 \mathrm{~mL})$. TBAF $(1 \mathrm{M}$ in THF, $2.74 \mathrm{~mL}$ ) was added to the solution, and the mixture was stirred at $45{ }^{\circ} \mathrm{C}$ for $4 \mathrm{~h}$. The solvent was cooled and the crystals were corrected to give $4(0.19 \mathrm{~g}, 0.65 \mathrm{mmol}, 71 \%):{ }^{1} \mathrm{H}$ NMR $\left(400 \mathrm{MHz}\right.$, DMSO- $\left.d_{6}\right): \delta=3.45(\mathrm{~s}, 1 \mathrm{H}), 4.59(\mathrm{~s}, 1 \mathrm{H}), 4.76(\mathrm{~s}$, $1 \mathrm{H}), 5.34(\mathrm{~s}, 1 \mathrm{H}), 6.52(\mathrm{~s}, 2 \mathrm{H}), 7.46(\mathrm{~d}, J=7.8,2 \mathrm{H}), 7.60(\mathrm{~d}, J=$ 7.8, 2H), $7.98(\mathrm{~s}, 1 \mathrm{H}), 10.73(\mathrm{~s}, 1 \mathrm{H}) .{ }^{13} \mathrm{C}$ NMR $(101 \mathrm{MHz}$, DMSO$\left.d_{6}\right): \delta=67.3,73.2,117.1,123.4,127.2,133.7,136.5,143.0,151.0$, 154.0, 157.1. HRMS (ESI): calcd for $\mathrm{C}_{13} \mathrm{H}_{13} \mathrm{~N}_{5} \mathrm{O}_{3}, 310.0916[\mathrm{M}+$ $\mathrm{Na}]^{+}$, found 310.0938 .

(S)-9-\{4-[1,2-Bis(tert-butyldimethylsilyloxy)ethyl]phenyl\}- $N^{2}$ [( $N, N$-dimethyl)aminomethylene]guanine (11). A mixture of $\mathbf{1 0}$ $(0.56 \mathrm{~g}, 1.08 \mathrm{mmol})$ and $N, N$-dimethylformamide dimethyl acetal $(0.72 \mathrm{~mL}, 5.43 \mathrm{mmol}, 5$ eq. $)$ in $\mathrm{MeOH}(5.6 \mathrm{~mL})$ was stirred at $40{ }^{\circ} \mathrm{C}$ for $7 \mathrm{~h}$. The resulting mixture was partitioned between $\mathrm{CHCl}_{3}$ and brine. The organic layer was dried $\left(\mathrm{Na}_{2} \mathrm{SO}_{4}\right)$, and concentrated. The residue was purified by column chromatography $\left(\mathrm{SiO}_{2}, 6 \% \mathrm{MeOH}\right.$ in $\left.\mathrm{CHCl}_{3}\right)$ to give $10(0.51 \mathrm{~g}, 0.90 \mathrm{mmol}$, 83\%): ${ }^{1} \mathrm{H}$ NMR (600 MHz, $\left.\mathrm{CDCl}_{3}\right): \delta=-0.03(\mathrm{~s}, 3 \mathrm{H}),-0.02(\mathrm{~s}$, $3 \mathrm{H}),-0.01(\mathrm{~s}, 3 \mathrm{H}), 0.10(\mathrm{~s}, 3 \mathrm{H}), 0.86(\mathrm{~s}, 9 \mathrm{H}), 0.90(\mathrm{~s}, 9 \mathrm{H}), 3.11(\mathrm{~s}$, $3 \mathrm{H}), 3.15(\mathrm{~s}, 3 \mathrm{H}), 3.55(\mathrm{dd}, J=5.5$ and $9.6,1 \mathrm{H}), 3.69(\mathrm{dd}, J=6.8$ and $10.3,1 \mathrm{H}), 4.76(\mathrm{t}, J=6.2,1 \mathrm{H}), 7.49(\mathrm{~d}, J=8.9,2 \mathrm{H}), 7.56(\mathrm{~d}, J$ $=8.3,2 \mathrm{H}), 7.83(\mathrm{~s}, 1 \mathrm{H}), 8.54(\mathrm{~s}, 1 \mathrm{H}), 9.42(\mathrm{~s}, 1 \mathrm{H}) .{ }^{13} \mathrm{C}$ NMR $(151$ $\left.\mathrm{MHz}, \mathrm{CDCl}_{3}\right): \delta=-5.5,-5.4,-4.8,-4.7,18.3,18.4,25.8,25.9$, 35.2, 41.3, 69.7, 75.3, 121.1, 123.2, 127.5, 134.0, 137.5, 142.7, 150.0, 156.8, 158.0. HRMS (ESI): calcd for $\mathrm{C}_{28} \mathrm{H}_{46} \mathrm{~N}_{6} \mathrm{O}_{3} \mathrm{Si}_{2}$, $571.3248[\mathrm{M}+\mathrm{H}]^{+}$, found 571.3256 .

$(S)-N^{2}$-[( $N, N$-Dimethyl)aminomethylene]-9-[4-(1,2-dihydroxy ethyl)phenyl]guanine (12). Compound $11(0.22 \mathrm{~g}, 0.39 \mathrm{mmol})$ was dissolved in THF ( $2 \mathrm{~mL}$ ). TBAF ( $1 \mathrm{M}$ in THF, $1.18 \mathrm{~mL}, 3$ eq.) was added to the solution, and the mixture was stirred at room temperature for $22 \mathrm{~h}$. The solvent was evaporated in vacuo, and the resulting residue was purified by column chromatography $\left(\mathrm{SiO}_{2}, 6-16 \% \mathrm{MeOH}\right.$ in $\left.\mathrm{CHCl}_{3}\right)$ to give $12(0.13 \mathrm{~g}, 0.39 \mathrm{mmol}$, 99\%): ${ }^{1} \mathrm{H}$ NMR (600 MHz, DMSO- $\left.d_{6}\right): \delta=3.01(\mathrm{~s}, 3 \mathrm{H}), 3.13(\mathrm{~s}$, $3 \mathrm{H}), 3.47$ to $3.50(\mathrm{~m}, 2 \mathrm{H}), 4.60(\mathrm{dd}, J=5.5$ and $11.0,1 \mathrm{H}), 4.77(\mathrm{t}, J$ $=5.5,1 \mathrm{H}), 5.34(\mathrm{~d}, J=4.1,1 \mathrm{H}), 7.50(\mathrm{~d}, J=8.3,2 \mathrm{H}), 7.73(\mathrm{~d}, J=$ 8.9, 2H), $8.16(\mathrm{~s}, 1 \mathrm{H}), 8.48(\mathrm{~s}, 1 \mathrm{H}), 11.42(\mathrm{~s}, 1 \mathrm{H}) .{ }^{13} \mathrm{C}$ NMR $(151$ MHz, DMSO- $\left.d_{6}\right): \delta=34.7,40.6,67.2,73.3,120.3,122.7,127.3$, 133.7, 137.5, 142.7, 149.5, 157.4, 157.7, 157.9. HRMS (ESI): calcd for $\mathrm{C}_{16} \mathrm{H}_{18} \mathrm{~N}_{6} \mathrm{O}_{3}, 343.1519[\mathrm{M}+\mathrm{H}]^{+}$, found 343.1521.

(S)-9-\{4-[2-(4,4'-Dimethoxytrityloxy)-1-hydroxyethyl]phenyl\}$N^{2}$-[( $N, N$-dimethyl)aminomethylene]guanine (13). A mixture of $12(0.25 \mathrm{~g}, 0.74 \mathrm{mmol})$ and DMTrCl $(0.38 \mathrm{~g}, 1.11 \mathrm{mmol}, 1.5 \mathrm{eq}$. in pyridine $(2 \mathrm{~mL})$ was stirred at room temperature for $2 \mathrm{~h}$. The mixture was partitioned between EtOAc and aqueous $\mathrm{NaHCO}_{3}$ 
(saturated). The organic layer was washed with brine, dried $\left(\mathrm{Na}_{2} \mathrm{SO}_{4}\right)$, and concentrated. The residue was purified by column chromatography $\left(\mathrm{SiO}_{2}, 5-16 \% \mathrm{MeOH}\right.$ in $\left.\mathrm{CHCl}_{3}\right)$ to give 13 (0.47 g, $0.72 \mathrm{mmol}, 98 \%):{ }^{1} \mathrm{H} \mathrm{NMR}\left(600 \mathrm{MHz}, \mathrm{CDCl}_{3}\right): \delta=$ $2.88(\mathrm{~d}, J=2.7,1 \mathrm{H}), 2.95(\mathrm{~s}, 3 \mathrm{H}), 3.05(\mathrm{~s}, 3 \mathrm{H}), 3.29(\mathrm{t}, J=8.2,1 \mathrm{H})$, $3.38(\mathrm{dd}, J=3.4$ and $10.3,1 \mathrm{H}), 3.78(\mathrm{~s}, 6 \mathrm{H}), 4.86(\mathrm{t}, J=3.4,1 \mathrm{H})$, $6.83(\mathrm{~d}, J=8.9,4 \mathrm{H}), 7.21$ to $7.30(\mathrm{~m}, 7 \mathrm{H}), 7.40(\mathrm{~d}, J=7.6,2 \mathrm{H})$, $7.45(\mathrm{~d}, J=8.3,2 \mathrm{H}), 7.53(\mathrm{~d}, J=8.3,2 \mathrm{H}), 7.78(\mathrm{~s}, 1 \mathrm{H}), 8.42(\mathrm{~s}$, $1 \mathrm{H}), 8.60(\mathrm{~s}, 1 \mathrm{H}) .{ }^{13} \mathrm{C} \mathrm{NMR}\left(151 \mathrm{MHz}, \mathrm{CDCl}_{3}\right): \delta=35.1,41.1$, 55.2, 69.0, 72.8, 86.6, 113.2, 121.0, 123.9, 126.9, 127.4, 127.9, $128.0,130.0,134.4,135.8,137.4,140.8,144.7,150.1,156.9$, 157.9, 158.0, 158.6. HRMS (ESI): calcd for $\mathrm{C}_{37} \mathrm{H}_{36} \mathrm{~N}_{6} \mathrm{O}_{5}, 645.2825$ $[\mathrm{M}+\mathrm{H}]^{+}$, found 645.2858 .

(S)-9-(4-\{1-[(2-Cyanoethoxy)(diisopropylamino)phosphanyloxy $]-2-\left(4,4^{\prime}\right.$-dimethoxytrityloxy $)$ ethyl $\}$ phenyl $)-N^{2}-[(N, N$-dimethyl $)$ aminomethylene]guanine (14). Compound $13(0.43 \mathrm{~g}, 0.67$ mmol) was dissolved in $\mathrm{CH}_{2} \mathrm{Cl}_{2}(4 \mathrm{~mL})$ containing $N, N$-diisopropylethylamine $(0.35 \mathrm{~mL}, 2.02 \mathrm{mmol}, 3 \mathrm{eq}$.). Chloro(2-cyanoethoxy)( $N, N$-diisopropylamino)phosphine $(0.23 \mathrm{~mL}$, $1.01 \mathrm{mmol}, 1.5$ eq.) was added to the solution, and the mixture was stirred at room temperature for $1 \mathrm{~h}$. Aqueous $\mathrm{NaHCO}_{3}$ (saturated) and $\mathrm{CHCl}_{3}$ were added to the mixture, and the separated organic layer was washed with aqueous $\mathrm{NaHCO}_{3}$ (saturated) and brine, dried $\left(\mathrm{Na}_{2} \mathrm{SO}_{4}\right)$ and concentrated. The residue was purified by column chromatograph (a neutralized $\mathrm{SiO}_{2}, 5-9 \% \mathrm{MeOH}$ in $\mathrm{CHCl}_{3}$ ) to give 14 (0.54 g, $\left.0.64 \mathrm{mmol}, 96 \%\right)$ :

${ }^{31} \mathrm{P}$ NMR (162 MHz, $\mathrm{CDCl}_{3}$ ): $\delta=149.3,149.8$. HRMS (ESI): calcd for $\mathrm{C}_{46} \mathrm{H}_{53} \mathrm{~N}_{8} \mathrm{O}_{6} \mathrm{P}, 845.3904[\mathrm{M}+\mathrm{H}]^{+}$, found 845.3903.

\section{Oligonucleotide synthesis}

The synthesis was carried out with a DNA/RNA synthesizer by the phosphoramidite method. Deprotection of DNAs was performed in concentrated $\mathrm{NH}_{4} \mathrm{OH}$ at $55{ }^{\circ} \mathrm{C}$ for $16 \mathrm{~h}$. Deprotection of RNAs was performed in concentrated $\mathrm{NH}_{4} \mathrm{OH} / \mathrm{EtOH}(3: 1$, v/ v) at $55{ }^{\circ} \mathrm{C}$ for $4 \mathrm{~h}$. $2^{\prime}$-O-TBDMS groups were removed by $\mathrm{Et}_{3}$ $\mathrm{N} \cdot 3 \mathrm{HF}$ in DMSO at $65^{\circ} \mathrm{C}$ for $90 \mathrm{~min}$. The reaction was quenched with $0.1 \mathrm{M}$ TEAA buffer ( $\mathrm{pH}$ 7.0) and the mixture desalted using a Sep-Pak C18 cartridge. The oligonucleotides were purified by 20\% PAGE containing $7 \mathrm{M}$ urea and/or reversed-phase C-18 HPLC using a gradient of solution A (5\% MeCN in $0.1 \mathrm{M}$ TEAA buffer, $\mathrm{pH} 7.0)$ and solution $\mathrm{B}(50 \% \mathrm{MeCN}$ in $0.1 \mathrm{M}$ TEAA buffer, $\mathrm{pH}$ 7.0).

\section{MALDI-TOF/MS analysis of ONS}

The spectra were obtained with a time-of-flight mass spectrometer equipped with a nitrogen laser ( $337 \mathrm{~nm}, 3 \mathrm{~ns}$ pulse). A solution of 3-hydroxypicolinic acid (3-HPA) and diammonium hydrogen citrate in $\mathrm{H}_{2} \mathrm{O}$ was used as the matrix. Data of synthetic ONs: DNA 1: $\mathrm{m} / \mathrm{z}=5145.40$ (calcd for $\mathrm{C}_{166} \mathrm{H}_{208} \mathrm{~N}_{65} \mathrm{O}_{96} \mathrm{P}_{16}[\mathrm{M}-\mathrm{H}]^{-}$5145.40); DNA 2: $\mathrm{m} / \mathrm{z}=5098.51$ (calcd for $\mathrm{C}_{164} \mathrm{H}_{208} \mathrm{~N}_{61} \mathrm{O}_{98} \mathrm{P}_{16}[\mathrm{M}-\mathrm{H}]^{-}$5097.35); DNA 3: $\mathrm{m} / \mathrm{z}=$ 5177.60 (calcd for $\mathrm{C}_{166} \mathrm{H}_{208} \mathrm{~N}_{65} \mathrm{O}_{98} \mathrm{P}_{16}[\mathrm{M}-\mathrm{H}]^{-}$5177.40); DNA 4: $m / z=5127.60$ (calcd for $\mathrm{C}_{166} \mathrm{H}_{210} \mathrm{~N}_{59} \mathrm{O}_{100} \mathrm{P}_{16}[\mathrm{M}-\mathrm{H}]^{-}$5127.37); DNA 5: $m / z=3919.72$ (calcd for $\mathrm{C}_{127} \mathrm{H}_{158} \mathrm{~N}_{53} \mathrm{O}_{70} \mathrm{P}_{12}[\mathrm{M}-\mathrm{H}]^{-}$ 3919.62); DNA 6: $m / z=3871.68$ (calcd for $\mathrm{C}_{125} \mathrm{H}_{158} \mathrm{~N}_{49} \mathrm{O}_{72} \mathrm{P}_{12}[\mathrm{M}$ - $\mathrm{H}]^{-}$3870.57); DNA 7: $m / z=5743.48$ (calcd for
$\mathrm{C}_{192} \mathrm{H}_{229} \mathrm{~N}_{76} \mathrm{O}_{101} \mathrm{P}_{17}[\mathrm{M}-\mathrm{H}]^{-}$5743.88); ON 1: $\mathrm{m} / z=5245.06$ (calcd for $\mathrm{C}_{181} \mathrm{H}_{208} \mathrm{~N}_{65} \mathrm{O}_{91} \mathrm{P}_{16}[\mathrm{M}-\mathrm{H}]^{-}$5245.57); ON 2: $\mathrm{m} / z=$ 5198.15 (calcd for $\mathrm{C}_{179} \mathrm{H}_{208} \mathrm{~N}_{61} \mathrm{O}_{93} \mathrm{P}_{16}[\mathrm{M}-\mathrm{H}]^{-}$5197.53); ON 3: $m / z=5277.04$ (calcd for $\mathrm{C}_{181} \mathrm{H}_{208} \mathrm{~N}_{65} \mathrm{O}_{93} \mathrm{P}_{16}[\mathrm{M}-\mathrm{H}]^{-}$5277.57); ON 4: $m / z=5228.18$ (calcd for $\mathrm{C}_{181} \mathrm{H}_{210} \mathrm{~N}_{59} \mathrm{O}_{95} \mathrm{P}_{16}[\mathrm{M}-\mathrm{H}]^{-}$ 5227.55); ON 5: $m / z=4018.86$ (calcd for $\mathrm{C}_{142} \mathrm{H}_{158} \mathrm{~N}_{53} \mathrm{O}_{65} \mathrm{P}_{12}[\mathrm{M}$ - $\mathrm{H}]^{-}$4018.79); $\mathrm{ON}$ 6: $\mathrm{m} / \mathrm{z}=3970.97$ (calcd for $\mathrm{C}_{140} \mathrm{H}_{158} \mathrm{~N}_{49} \mathrm{O}_{67} \mathrm{P}_{12}[\mathrm{M}-\mathrm{H}]^{-}$3970.75); ON 7: $\mathrm{m} / \mathrm{z}=5844.20$ (calcd for $\mathrm{C}_{207} \mathrm{H}_{229} \mathrm{~N}_{76} \mathrm{O}_{96} \mathrm{P}_{17}[\mathrm{M}-\mathrm{H}]^{-}$5844.05); RNA 1: $m / z=$ 5389.64 (calcd for $\mathrm{C}_{161} \mathrm{H}_{196} \mathrm{~N}_{59} \mathrm{O}_{121} \mathrm{P}_{16}[\mathrm{M}-\mathrm{H}]^{-}$5389.19); RNA 2: $m / z=5467.74$ (calcd for $\mathrm{C}_{163} \mathrm{H}_{198} \mathrm{~N}_{65} \mathrm{O}_{119} \mathrm{P}_{16}[\mathrm{M}-\mathrm{H}]^{-}$ 5467.27); RNA 3: $m / z=5387.00$ (calcd for $\mathrm{C}_{161} \mathrm{H}_{198} \mathrm{~N}_{61} \mathrm{O}_{119} \mathrm{P}_{16}[\mathrm{M}$ - $\mathrm{H}]^{-}$5387.22); RNA 4: $m / z=5436.10$ (calcd for $\mathrm{C}_{163} \mathrm{H}_{198} \mathrm{~N}_{65} \mathrm{O}_{117} \mathrm{P}_{16}[\mathrm{M}-\mathrm{H}]^{-}$5435.27); RNA 5: $m / z=4080.14$ (calcd for $\mathrm{C}_{122} \mathrm{H}_{148} \mathrm{~N}_{41} \mathrm{O}_{95} \mathrm{P}_{12}[\mathrm{M}-\mathrm{H}]^{-}$4080.39); RNA 6: $m / z=$ 4158.26 (calcd for $\mathrm{C}_{124} \mathrm{H}_{150} \mathrm{~N}_{47} \mathrm{O}_{93} \mathrm{P}_{12}[\mathrm{M}-\mathrm{H}]^{-}$4158.47); RNA 7: $m / z=5927.30$ (calcd for $\mathrm{C}_{188} \mathrm{H}_{221} \mathrm{~N}_{60} \mathrm{O}_{130} \mathrm{P}_{17}[\mathrm{M}-\mathrm{H}]^{-}$5927.65); RNA 8: $m / z=4618.50$ (calcd for $\mathrm{C}_{149} \mathrm{H}_{173} \mathrm{~N}_{42} \mathrm{O}_{104} \mathrm{P}_{13}[\mathrm{M}-\mathrm{H}]^{-}$ 4618.85).

\section{Thermal denaturation study}

The solution containing the duplex in a buffer comprising $10 \mathrm{mM}$ sodium phosphate (pH 7.0) and $100 \mathrm{mM} \mathrm{NaCl}$ was heated at $100{ }^{\circ} \mathrm{C}$ for $5 \mathrm{~min}$, cooled gradually to an appropriate temperature, and then used for the thermal denaturation study. The thermally induced transition of each mixture was monitored at $260 \mathrm{~nm}$ with a UV/vis spectrometer fitted with a temperature controller in quartz cuvettes with a path length of $1.0 \mathrm{~cm}$ and a $3.0 \mu \mathrm{M}$ duplex concentration in a buffer of $10 \mathrm{mM}$ sodium phosphate $(\mathrm{pH} 7.0)$ and $0.1 \mathrm{M} \mathrm{NaCl}$. The sample temperature was increased by $0.5{ }^{\circ} \mathrm{C} \mathrm{min}^{-1}$. The thermodynamic parameters of the duplexes on duplex formation were determined by calculations based on the slope of a $1 / T_{\mathrm{m}} v s$. $\ln \left(C_{\mathrm{T}} / 4\right)$ plot, where $C_{\mathrm{T}}(1,3,6,12,15,21,30$, and $60 \mu \mathrm{M})$ is the total concentration of single strands.

\section{Partial hydrolysis of ONs in a buffer containing bovine serum}

Each ON (3000 pmol) labeled with fluorescein at the $5^{\prime}$-end was incubated with $30 \%$ bovine serum in a buffer $(150 \mu \mathrm{L})$ comprised of $0.1 \mathrm{M}$ Tris- $\mathrm{HCl}(\mathrm{pH} 8.0)$ and $20 \mathrm{mM} \mathrm{MgCl}_{2}$ at $37{ }^{\circ} \mathrm{C}$. Aliquots $(5 \mu \mathrm{L})$ were taken at $0,0.5,1,5,30,60,180$, $360 \mathrm{~min}$ and mixed with the loading buffer $(15 \mu \mathrm{L})$ containing Tris-borate-EDTA (TBE) buffer and 20\% glycerin on ice. Each sample was analyzed by $20 \%$ denaturing PAGE at room temperature at $20 \mathrm{~mA}$ for $2 \mathrm{~h}$. The gel was visualized by use of a Luminescent Image analyzer LAS-4000 (Fujifilm).

\section{DNA constructs}

A DNA fragment of $E$. coli mal $E$ gene encoding maltose binding protein (MBP) and a fragment encoding catalytic domain of human RNase H1 (residues 136-286, H-domain) were subcloned into the multiple cloning site of pET15b, resulting in pET-MBPhRNase H1 (H-domain) vector for expressing MBP-hRNase H1 (H-domain) fusion protein. Between the two genes, a specific cleavage site for human Rhinovirus 3C (HRV3C) protease was 
engineered. All the DNA fragments were prepared by the standard PCR method.

\section{Protein expression and purification}

The pET-MBP-hRNase H1 (H-domain) vector was transformed into $E$. coli BL21(DE3). The cells were cultured in Luria-Bertani medium at the $37{ }^{\circ} \mathrm{C}$ until $\mathrm{OD}_{600}$ reached to approximately 0.4 . Final $0.2 \mathrm{mM}$ of isopropyl- $\beta$-D-galactoside was added to induce the recombinant protein expression, and the temperature was shifted to $20{ }^{\circ} \mathrm{C}$. After 20 hours, the cells were harvested. The bacterial cells were suspended to the lysis buffer ( $\mathrm{pH} 7.0$ ) containing $40 \mathrm{mM}$ sodium phosphate, $1 \mathrm{M} \mathrm{NaCl}, 0.5 \mathrm{mM}$ EDTA and $2 \mathrm{mM}$ dithiothreitol (DTT). Then, the cells were lysed by sonication, and the supernatant was collected by centrifugation. First, a cleared supernatant was passed through DEAESepharose® (GE Healthcare Life Sciences Corp, Piscataway, NJ, USA), and then the fusion protein was captured by Amylose resin (New England Biolabs, Ipswich, MA, USA). From the fusion protein, MBP tag was removed by on-column digestion by adding HRV3C protease at room temperature. The digested hRNase H1 (H-domain) was purified by cation exchange chromatography by using SP-Sepharose ${ }^{\circledR}$ (GE Healthcare Life Sciences) and further purified by gel-filtration by Superdex® 75 pg (GE Healthcare Life Sciences). Finally, the enzyme was dialyzed against $20 \mathrm{mM}$ sodium phosphate buffer ( $\mathrm{pH}$ 7.0) containing $100 \mathrm{mM} \mathrm{NaCl}$ and $5 \mathrm{mM}$ DTT.

\section{Hydrolysis of RNA with human recombinant RNase H1}

The solution containing ON (600 pmol) and RNA (3000 pmol) labeled with fluorescein at the $5^{\prime}$-end in a buffer comprised of $50 \mathrm{mM}$ Tris- $\mathrm{HCl}$ (pH. 8.0), $75 \mathrm{mM} \mathrm{KCl,} 3 \mathrm{mM} \mathrm{MgCl}_{2}$ and $10 \mathrm{mM}$ dithiothreitol was heated at $100{ }^{\circ} \mathrm{C}$ for $5 \mathrm{~min}$. The reaction mixtures were then cooled gradually to an appropriate temperature. Then human RNase H1 (2 pmol) was added to the solution, and the mixture was incubated at $37^{\circ} \mathrm{C}$. Aliquots $(5 \mu \mathrm{L})$ were taken at $0,1,5,15,30,60,120$ and $240 \mathrm{~min}$, and mixed with formamide $(15 \mu \mathrm{L})$ on ice. Each sample was analyzed by $20 \%$ denaturing PAGE at room temperature at $20 \mathrm{~mA}$ for $2 \mathrm{~h}$. The gel was visualized by use of a Luminescent Image analyzer LAS-4000 (Fujifilm).

\section{Notes and references}

1 (a) P. C. Zamecnik and M. L. Stephenson, Proc. Natl. Acad. Sci. U. S. A., 1978, 75, 280-284; (b) M. L. Stephenson and P. C. Zamecnik, Proc. Natl. Acad. Sci. U. S. A., 1978, 75, 285288.

2 (a) M. Muthiah, Antisense Nucleic Acid Drug Dev., 2002, 12, 103-128; (b) T. Aboul-Fadl, Curr. Med. Chem., 2005, 12, 2193-2214.

3 P. M. D. Moreno and A. P. Pêgo, Front. Chem., 2014, 2, 87, DOI: $10.3389 /$ chem.2014.00087.

4 Editorial, Nat. Biotechnol., 2016, 34, 1078, DOI: 10.1038/ nbt.3733.

5 (a) Y. Ueno, T. Kato, K. Sato, Y. Ito, M. Yoshida, T. Inoue, A. Shibata, M. Ebihara and Y. Kitade, J. Org. Chem., 2005, 70, 7925-7935; (b) Y. Ueno, A. Kawamura, K. Takasu, S. Komatsuzaki, T. Kato, S. Kuboe, Y. Kitamura and Y. Kitade, Org. Biomol. Chem., 2009, 7, 2761-2769; (c) N. Niwa, K. Ueda and Y. Ueno, Eur. J. Org. Chem., 2016, 2435-2443.

6 Y. Yue, Z.-G. Zheng, B. Wu, C.-Q. Xia and X.-Q. Yu, Eur. J. Org. Chem., 2005, 5154-5157.

7 M. F. Jacobsen, M. M. Knudsen and K. V. Gothelf, J. Org. Chem., 2006, 71, 9183-9190.

8 M. Nowotny, S. A. Gaidamakov, R. Ghirlando, S. M. Cerritelli, R. J. Crouch and W. Yang, Mol. Cell, 2007, 28, 264-276. 